\title{
Pielonefritis crónica
}

DR. FEUERICO PUGA C. *.

La pielonefritis crónica es el comienzo del epílogo, muchas veces fatal, de una infección urinaria no diagnosticada o mal tratada. Es la causa más corriente de la insuficiencia renal crónica, y de la hipertensión arterial en la infancia, frecuencia que sigue predominando en el adulto.

Es indudable por los datos mencionados en los anteriores correlatos que existen infecciones urinarias con y sin compromisos del parénquima renal para to que existen algunos medios clínicos para precisarlo, pero la pielonefritis debemos buscarla, diría que con insistencia, entre las infecciones urinarias recidiyantes con mala respuesta terapéutica, tras la sospecha de una mal formación del árbol urinario, fuente primordial en la provisión de riñones pielonefríticos.

La frecuencia de la pielonefritis es todavía desconocida pero existen algunos antecedentes cntre nosotros y en el extranjero que bien vale la para presentar (Tabla No i).

\section{T A B L A Nọ 1}

\section{FRECUENCIA DE PIELONEFRITIS}

Infección Urinaria

I. U. Asintomática

I. U. con Pielonefritis

Pielonefritis Radiológica

Pielonefritis Crónica

Porcentaje de Autopsia
8 a $12 \times 1000$ hab. Mand, 1964 $5 \%$ a $\operatorname{los} 18$ años. Kunin, 1968 33\% Masters, 1966 $27 \%$ Wittaker, 1971

$26 \%$ Smellie, 1964

$2 \%$ Colby, 1959

2,6\% Spark, 1962

$1,6 \%$ Neumann, 1962

2,3\% Calvo Mackenna, 1972.

"Depto. Neftodogia. Huspital Calvo Mackenna.

Los médicos de adultos nos critican y con razón, de ser los culpables inocentes de sus pacientes pielonefríticos, pero vimos en otro correlato que la infección urinaria y aún mass, la pielonefritis puede presentarse con cualquier ropaje. Sólo el examen bacteriológico de orina nos permitirá fundar un diagnóstico acertado de infección urinaria. Sin embargo, este mismo criterio diagnóstico no puede aplicarse a la pielonefritis crónica, pues en ella encontramos sólo un $61 \%$ de urocultivos positivos; sólo 2 de cada 3 pacientes dan el antece. dente de infección urinaria previa $\mathrm{y}$, en el momento de la consulta, sólo el $32 \%$ refieren sus molestias al árbol urinario mientras los restantes tienen molestias abdominales o ya signos propios de la insuficiencia renal crónica. (Tabla Nọ 2).

$$
\text { TABLA No } 2
$$

DIFICULTAD DIAGNOSTICA DE LA PIELONEFRITIS CRONICA

\begin{tabular}{lccc}
\hline & $\begin{array}{c}\text { Calvo } \\
\text { Mackenna }\end{array}$ & $\begin{array}{c}\text { Otros } \\
\text { Autores }\end{array}$ \\
\hline $\begin{array}{l}\text { Recuentos Bacterianos } \\
+100.000 \text { x ml. }\end{array}$ & 39 & 30,1 (Ambrose) \\
$\begin{array}{l}\text { Antecedentes de I. } \\
\text { Urinaria }\end{array}$ & 64 & 42 & (Smellie) \\
Síntomas urinarios & 32 & 35 & (Smellie) \\
\hline
\end{tabular}

Nuestra casuística está representada por 31 pacientes con pielonefritis crónica demostrada en 28 pacientes con estudio histopatológico por biopsía, generalmente quirúrgica, o autopsia (Tabla No 3). 
PIELONEFRITIS CRONICA 31 CASOS

\begin{tabular}{lr}
\hline Intervención quirúrgica & $25 \operatorname{casos}(74,5 \%)$ \\
Estudio Histológico por Biopsia & $16 \operatorname{casos}(51,6 \%)$ \\
Autopsias & $4 \operatorname{casos}(12 \%)$ \\
Fallecidos & $9 \operatorname{casos}(28 \%)$ \\
\hline
\end{tabular}

\section{T A B L A No 4 \\ ELEMENTOS DIAGNOSTICOS DE PIELONEFRITIS CRONICA 31 CASOS}

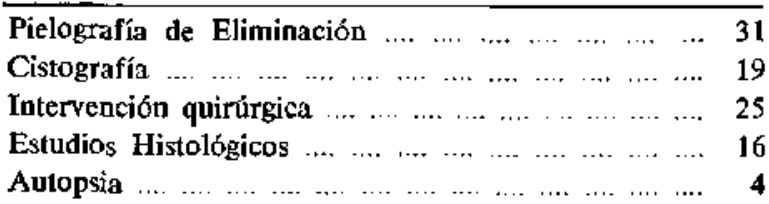

TAB L A No 5

ESTADO FUNCIONAL AL INGRESO. 31 PIELONEFRITIS CRONICAS DEPTO. NEFROUROLOGLA. HOSPITAL L. CALVO MACKENNA

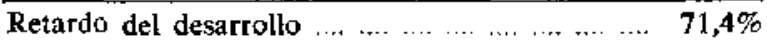

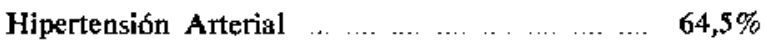

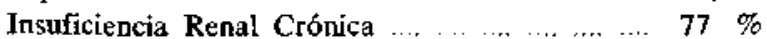

En tres pacientes no tenemos la comprobación histológica pero el cuadro clínico y radiológico son muy evidente y en éstos la intervención quirúrgica fue sobre el árbol urinario bajo, no pudiendo obtenerse biopsia renal. En estos 31 pacientes se usaron diversos elementos diagnóstico (Tála 4).

El diagnóstico es evidentemente tardío, por las raones ya expuestas, existiendo elementos clínicos y de laboratorio de insuficiencia renal como se observa en la tabla 5.

Los 31 pacientes tienen por lo menos una pielografía de eliminación y, en todas a menos una, existe alteración en el tránsito de la orina, con los diagnósticos que se presentan en cl cuadro 6 .
INFORMACION RADIOLOGICA EN 31 PACIENTES CON PIELONEFRITIS CRONICA

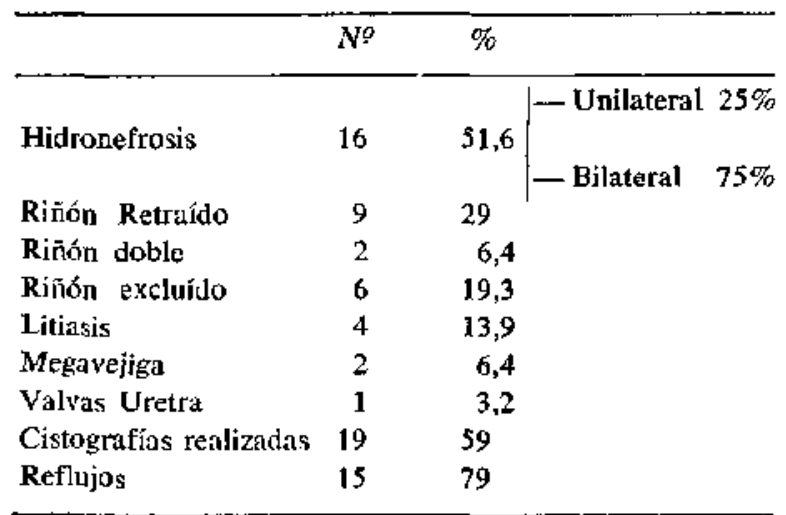

La cistografía se realizó en 19 de ellos y en $15(79 \%)$ ésta demostró reflujo.

El único caso de pielonefritis primaria se ha tratado clínicamente durante tres años con Nitrofurantoína con resultados muy favorables, ya que en $1970 \mathrm{la}$ Osm. máxima fue de 305 y el Cler de $16 \mathrm{ml} . / \mathrm{min} . / 1,73 \mathrm{~m}^{2}$ y en 1972 la Osm. subió a 745 y el Cler a 83 .

Habitualmente estas malformaciones son operables, lo que ocurrió en el $75 \%$ de nuestros pacientes y la evolución postoperatoria ha sido satisfactoria. Sin embargo, la insuficiencia renal no hace aconsejable la intervención, ya que las posibilidades de recuperación son escasas. De todos modos, cada paciente debe ser analizado en particular.

Para terminar, creemos que la infección urinaria debe buscarse en aquellos cuadros dudosas y una vez confirmada, realizar estudios uroradiológicos completos y tratamientos acabados de controles prolongados de por lo menos 2 años, con el fin de prevenir más de uno de estos desastres. El riñón del niño es agradecido. Si hemos llegado tarde, la vida podrá prolongarse con tratamientos sintomáticos sobre la presión arterial, las perdidas salinas, la retención catabólica, el PH y la retención de agua en la espera de que en un futuro no muy lejano se abran las espectativas del beneficio del trasplante renal en nuestro país. 